\title{
El vídeo musical como formato postmoderno: La ruptura de los códigos audiovisuales a través del clip
}

\section{Music Video as postmodern format: The rupture of audiovisual codes through music video}

Jennifer Rodríguez-López. Universidad de Huelva (jennifer.rodriguez@dedu.uhu.es)

Recibido el: 23/06/15 - Aceptado el: 28/09/15

\section{Resumen:}

En este artículo se comparan las características de la era postmoderna con los rasgos propios del vídeo musical que resultan coincidentes, definiendo el videoclip como un formato esencialmente postmoderno. Se proponen ejemplos del clip que evidencian aspectos como la ruptura de los códigos del lenguaje visual clásico, la velocidad o la repetición, la intertextualidad, entre otros. Esta reflexión se encuentra asistida por numerosos ejemplos de vídeos musicales que aluden a las características descritas y que destacan por su actualidad y estéticas originales. Se subraya cómo la postmodernidad actúa como contexto en el que se enmarca el vídeo musical como producto mass-mediático así como su carácter transgresor respecto al resto de lenguajes establecidos, de los que recibe influencias directas.

Palabras clave:

Vídeo musical; postmodernidad; formato; pastiche; códigos

\section{Abstract:}

In this paper the characteristics of the postmodern era are compared to the features of the music video that are coincident, defining the music video as an essentially postmodern format. It's proposed clip's examples that show aspects like breaking the classic visual language codes, speed, repetition, intertextuality, and others. This reflection is based on numerous examples of music videos that show the features described and characterized by their current and original aesthetic. It accentuates how postmodernism is the context in which the music video frames as a mass-media product and transgressive nature compared to other established languages, which receives direct influences.

\section{Keywords:}

Music Video; Postmodernism; Format; Pastiche; Codes 


\section{Introducción}

En este artículo se exponen las características de la era postmoderna, extraídas a partir de las afirmaciones de sus principales teóricos, para extrapolarlas a la naturaleza del vídeo musical como su formato paradigmático. Por ello, en primer lugar es necesaria la breve exposición del concepto de postmodernidad aplicado en este trabajo. Dicho término define una realidad opuesta a los valores estéticos de la modernidad, como es el gusto por lo sublime desde la nostalgia (Lyotard, 1996: 25). Dicha expresión se explica como la presencia en la obra de una idea irrepresentable que se encuentra ausente y por la que el espectador siente una sensación nostálgica que solo es cubierta con la representación de las formas de una manera reconocible.

Así, la experiencia estética sublime se consigue a través de una mezcla de placer y pena: placer ante la imagen representada y pena por la ausencia de la idea. En la postmodernidad, y es aquí donde el autor marca la diferencia, la representación "se niega a la consolación de las formas bellas", ya que todo concepto es posible.

Para Vattimo (1994: 14) la postmodernidad se encuentra relacionada con los medios de comunicación de masas, cuya aparición provoca la conclusión de la modernidad. El protagonismo de los mass media desencadena la aparición de un nuevo modelo de sociedad, caracterizada por la complejidad y el caos. En esta línea, el autor afirma que los mercados se encuentran en continua ampliación, exigiendo "en consecuencia que 'todo', en cierto modo, venga a ser objeto de comunicación".

En este sentido de ruptura y fin de la modernidad, Harris (2000: 154) utiliza en su definición de la era postmoderna palabras como "cuestionamiento", "rechazo" y "desdén" para configurar una realidad basada en el relativismo que niega la idea de progreso y del método científico: "Para los posmodernos no hay dogmas sagrados. La ciencia no se acerca más a la verdad que cualquier otra 'lectura' de un mundo incognoscible e indeterminable”. Según su visión, la postmodernidad supone la vuelta a "la emoción, las sensaciones, la introspección, la intuición, la autonomía, la creatividad, la imaginación, la fantasía y la contemplación”, que aboga por una realidad local, relativa e interpretativa, alejándose así de la modernidad en la que primaba la razón, la ciencia y la objetividad.

En síntesis, la postmodernidad se define por la renuncia a la idea de progreso colectivo en favor del progreso individual, el paso de una economía de la producción a una economía del consumo en la que los medios de comunicación de masas ocupan un lugar central, convertidos en los nuevos ejes del poder. Los mass media se erigen como transmisores de la verdad y los espectadores se encuentran saturados de información. Asimismo, la imagen se establece como pilar esencial de la identidad personal ya que la forma importa más que el contenido de los mensajes, lo que en los individuos se deriva en el culto al cuerpo y en el camino hacia la liberación personal.

Por otra parte, la política y la religión son profundamente cuestionadas, siendo ocupado su papel casi divino por la tecnología, en la que la sociedad mantiene una fe férrea. La postmodernidad supone la ruptura con todo lo anterior, el

14 | n 22, pp. 13-30 | doxa.comunicación 
cuestionamiento de todo lo establecido por la modernidad y la supremacía de las representaciones particulares por encima del hecho colectivo.

En el ámbito del arte y de los medios audiovisuales, como el cine y la televisión, existen características específicas de la postmodernidad como son la relajación de las fronteras inter-géneros, la intertextualidad, el gusto por el fragmento sobre la totalidad y el abandono de la belleza en favor de la representación de cualquier forma aunque pueda resultar antiestética, entre otras. Para Sánchez-Noriega (1997: 309) la postmodernidad se caracteriza fundamentalmente por la fragmentación, lo efímero y lo mudable en sustitución de los grandes relatos basados en principios que tratan de explicar el mundo. También se califica en relación al eclecticismo y al relativismo, con la consecuente crisis de los valores tradicionales, así como el culto a la novedad en todos los aspectos de la sociedad y la presencia del humor, la ironía y la parodia. Sobre el discurso televisivo, González-Requena (1999) subraya las siguientes características: fragmentación, combinación heterogénea de géneros, multiplicidad, carencia de clausura y carácter polifónico de la enunciación.

Por su parte, el videoclip se define en este artículo como un producto audiovisual y promocional de la industria discográfica que toma influencias directas del lenguaje cinematográfico, publicitario y de las vanguardias artísticas. Fruto de la era postmoderna, supone la traducción en códigos visuales de una canción mediante el uso de novedosas e impactantes técnicas digitales que pretenden seducir al espectador y que forjan una imagen de marca alrededor del cantante.

Una de las primeras delimitaciones del concepto de videoclip en nuestro país es la aportada por Durá (1988: 12) en la que es denominado como "una serie de realizaciones audiovisuales destinadas a fomentar el consumo musical entre los sectores juveniles de la sociedad". Este autor alude, como rasgo principal, a su naturaleza audiovisual y a su esencia promocional, en particular, dirigido a un target de público joven.

En este sentido, Sedeño (2008: 751) concluye que los videoclips "son producciones audiovisuales desarrolladas por el mercado de la música, una industria que genera no pocos beneficios, y dirigidas fundamentalmente a los jóvenes”, incidiendo en las mismas ideas que Durá dos décadas antes. Se evidencia la intención del vídeo musical en relación con la industria cultural al ser un producto de las compañías discográficas, sirviendo de estrategia publicitaria para la promoción de la música en su forma material. Leguizamón (2001: 254) afirma que "es un producto insertado en una estrategia de comercialización que responde a la potenciación de la obra musical a través de una obra visual que se ensambla con la forma musical". Asimismo, mantiene relación con otras industrias culturales como el cine, la televisión, la publicidad, el arte, la vídeo-creación, la fotografía, el cómic y la danza, entre otros.

Sánchez-López (2002: 566) determina que se trata de "una creación audiovisual de vocación cinematográfica surgida al calor del mundo contemporáneo y el vendaval massmediático, un testigo excepcional de las expectativas e inquietudes de las subculturas y tribus urbanas, un reclamo consumista para la juventud en su calidad de soporte publicitario de los pro- 
ductos de la industria discográfica y un vehículo para la autoafirmación y/o difusión y/o propaganda de los respectivos grupos y movimientos que alientan e inspiran su génesis al identificarse con una declaración de intenciones, un código 'ético' y una forma determinada de vivir, comportarse y pensar, siendo también consecuentemente un documento antropológico polivalente, contradictorio y versátil”. Es una de las definiciones del videoclip más completa ya que en ella refleja la influencia del cine y la publicidad y su naturaleza de difusión masiva como mecanismo de promoción de la industria discográfica, en relación con los colectivos sociales actuales y con el afán consumista.

De modo más sintético, y de vuelta a la definición de Durá, Roncero-Palomar (2008: 20) afirma que "un vídeo musical es una obra audiovisual, de intención fundamentalmente promocional, ya sea de la banda/artista o del tema musical, de 3 o 4 minutos de duración, en la que, por lo general, se presenta a una banda/artista interpretando el tema, a veces acompañada de imágenes con valor narrativo propio y otras, con un valor poético". En ella aparecen los elementos comunes sobre la condición audiovisual del clip y su objetivo comercial, así como se apela a su duración como elemento diferenciador con otros formatos y el valor añadido basado en la narración y en la expresión estética.

\section{Metodología}

El principal objetivo de este artículo es el de comparar los rasgos de la postmodernidad con las características del vídeo musical como producto audiovisual fruto de la era en la que nace y difundido a través de los medios de comunicación masivos. Otros objetivos fundamentales son vincular el vídeo musical con la postmodernidad, evidenciar las relaciones entre ambos como producto de la época actual y describir los rasgos del videoclip desde la perspectiva de la era postmoderna. Para ello, la metodología seguida se basa en la descripción para su posterior comparación de cada uno de estos rasgos. Este método se define como el procedimiento de la comparación sistemática de casos de análisis que en su mayoría se aplica con fines de generalización empírica y de la verificación de hipótesis. Ariza y Gandini (2012: 500) afirman que se basa en la "descripción y la explicación de las condiciones y los resultados semejantes y diferentes (usualmente estos últimos), entre unidades sociales grandes, naciones, sociedades y culturas”.

Estas autoras puntualizan que el método comparativo también puede ser entendido como "el análisis sistemático de observaciones extraídas de dos o más entidades macrosociales -o de varios momentos en la historia de una sociedad-para analizar sus semejanzas y diferencias e indagar sus causas". En este artículo, la comparación se aplica a las características de la postmodernidad extrapoladas al videoclip. Así, dichos aspectos sobre la postmodernidad han sido extraídos de las afirmaciones de los autores expuestos en la introducción.

Para conseguir la finalidad propuesta en este estudio se ha realizado una comparativa de ambas realidades -postmodernidad y vídeo musical- a partir de diferentes partes: pastiche y flujo constante de imágenes; repetición, recargamiento 
visual y velocidad; fragmentación y narración; transdiscursividad; espectáculo, seducción e impacto. Estos aspectos se desarrollarán a continuación de forma pormenorizada.

\section{La postmodernidad y el vídeo musical}

El vídeo musical se ha definido como un formato postmoderno que reúne las características de esta era. La ruptura de los códigos audiovisuales es uno de los principales rasgos del videoclip. Para Sedeño (2006: 746) "la variedad formal y narrativa que viene desarrollando [el vídeo musical] lo convierten en el mensaje o formato audiovisual más definidor de la cultura posmoderna". Los distintos aspectos de la postmodernidad que tienen su reflejo en el vídeo musical serán expuestos a continuación para su análisis pormenorizado y acompañado de ejemplos que faciliten su comprensión.

\subsection{Pastiche y flujo constante de imágenes}

El concepto de pastiche hace referencia al resultado de combinar elementos diversos ya existentes y cuyo resultado se ofrece como original. Es una mezcla de componentes ya conocidos para la creación de algo novedoso, pero que resulta ser un plagio. Jameson (1999: 18) asocia este término con la postmodernidad. Para el autor, el pastiche es uno de los rasgos más importantes de dicha era y lo define como una práctica. En su delimitación del concepto lo aparta de la parodia, con la que generalmente es confundido. Su discurso comienza acercando ambas nociones y afirma que "tanto el pastiche como la parodia implican la imitación, o mejor aún, el remedo de otros estilos y, en particular, de sus manierismos y crispamientos estilísticos".

Continúa su línea de pensamiento explicando la diferencia y aludiendo al carácter satírico de la parodia sobre el original, ya que mantiene una relación casi cómica con este, tomando de él sus aspectos más singulares para adaptarlos en forma de burla. Su exposición sobre estos conceptos finaliza con la siguiente afirmación: "El pastiche es una parodia vacía, una parodia que ha perdido su sentido del humor". A través del rasgo burlesco que se asocia a la parodia, se delimita la realidad del pastiche que permite la re-significación de los discursos audiovisuales a través de referencias que se alejan de los efectos cómicos.

Así, el vídeo musical se conforma a través del pastiche, mediante la relación y la influencia de otros medios que van desde el cine, la televisión y la publicidad hasta el cómic, la literatura y la videocreación. El videoclip lo aglutina todo y crea un nuevo producto que, sin embargo, recuerda a otros sin copiarlos. Es el homenaje del formato a sus predecesores y a sus congéneres.

Sedeño (2006: 747) observa en este hecho una de las razones por las que el vídeo musical es el medio audiovisual más definidor de la cultura postmoderna y afirma que es un formato cercano al publicitario que gracias a una investigación 
constante de nuevas técnicas ha conformado un lenguaje único. Asimismo subraya la variedad formal y narrativa de la que goza y la libertad e innovación de la que disfruta y que le ha llevado a convertirse en un "modelo de la vanguardia audiovisual contemporánea”. Por tanto, el pastiche se observa en la relación con otros medios como la publicidad y el vídeo de creación, así como en la libertad con la que se combinan los elementos extraídos de estos otros géneros audiovisuales creando un collage audiovisual.

Dicha libertad no solo se observa en el vídeo musical en su técnica, haciendo uso tanto de las nuevas tecnologías como de los dispositivos audiovisuales tradicionales, sino también en la estética. La influencia de otros medios y del arte hacen del videoclip un género ecléctico y vanguardista "donde se fraccionan las normas impuestas por la gramática audiovisual para denotar una cierta libertad de disposición de las imágenes” (Gómez-Alonso, 2001: 78), creando un lenguaje propio totalmente alejado del estilo cinematográfico clásico, pero al mismo tiempo tomando recursos formales y estéticos de este.

El siguiente rasgo, que une a la era postmoderna con el vídeo musical, es el flujo constante de imágenes. El videoclip se ha tomado frecuentemente como un claro ejemplo de la estética de los discursos visuales postmodernos (Gómez-Alonso, 2001: 77), aludiendo a esa fluctuación basada en la repetición de las imágenes a gran velocidad y de forma fragmentaria. En él, la linealidad narrativa se encuentra rota y el discurso visual se construye a partir de la sucesión de imágenes de forma aleatoria. Lipovetsky (2004: 240) observa en este hecho la culminación de lo que ha denominado como "cultura express", afirmando que "no se trata de evocar un universo irreal o de ilustrar un texto musical, se trata de sobreexcitar el desfile de imágenes y cambiar por cambiar, cada vez más rápido y cada vez con más imprevisibilidad y combinaciones arbitrarias y extravagantes". Bajo su óptica, el vídeo musical no trata de dotar a una canción de una representación icónica sino que es fruto de lo postmoderno, por lo que se define como un caudal visual en el que predomina la mutabilidad. Para el autor, el videoclip carece de pretensiones, sirviendo únicamente de paradigma de su época en la que lo visual ha tomado un cariz casi nihilista propio de la sociedad del entretenimiento.

Este rasgo se encuentra presente en todos los vídeos musicales, incluso en los de tipo minimalista. Sirve como ejemplo el videoclip de Sinead O’Connor “Nothing Compares 2U” (1990), dirigido por John Maybury. El vídeo presenta casi en su totalidad un primer plano fijo del rostro de la cantante mientras interpreta la canción, el fondo permanece en negro para dar mayor protagonismo a la intérprete y dotar a las imágenes de dramatismo. También se intercalan y superponen otras imágenes del entorno que se presenta al inicio del clip. A pesar de ser un vídeo en el que los elementos propios del género aparecen reducidos a su mínima expresión, se observan los rasgos principales del formato, como es la sucesión de planos, percibida en las partes en las que la artista pasea por el escenario presentado.

En el lado opuesto, con gran profusión de imágenes y cambios, se encuentra el vídeo musical realizado para el tema "Smack my Bitch up” (1997) del grupo The Prodigy y dirigido por Jonas Åkerlund. Este vídeo musical se ha convertido en el ideal 
del cambio, ya que, apoyado en el ritmo frenético de la banda sonora, narra la historia de una noche de fiesta salvaje de su protagonista. La sensación de inestabilidad y de cambio es acentuada por el continuo movimiento de la cámara que presenta la acción desde un plano subjetivo, ya que la actuación del protagonista es contemplada por el espectador a través de sus propios ojos. De este modo, el receptor debe mantenerse atento a los acontecimientos presentados para seguir el hilo de la narración. Todos los elementos contribuyen a la sensación de velocidad de la que se parte ya en la banda sonora.

Ambos vídeos ofrecen una muestra de la enorme heterogeneidad que caracteriza este género audiovisual. Sin embargo, no puede obviarse que siendo la canción la base de la estructura icónica, a cada subgénero musical corresponderán unos códigos visuales. Es decir, no pueden aplicarse los mismos códigos a una canción melódica como la interpretada por Sinead O’Connor que a una canción tan transgresora como "Smack my Bitch up". No obstante, queda patente que a pesar de esas diferencias tan sobresalientes, se mantienen unas estructuras y relaciones que permiten designar el estilo clip, convirtiendo a estos vídeos en paradigmas del videoclip minimalista y del videoclip frenético. En estos ejemplos se aprecia cómo la imagen se ha adaptado a la estructura musical, por lo que resultan configuraciones visuales muy diferentes pero fieles a la canción para las que fueron creadas.

\subsection{Repetición, recargamiento visual y velocidad}

Siguiendo con las características de la postmodernidad relacionadas con el vídeo musical, se analiza a continuación la repetición como uno de los rasgos de lo que se ha denominado como era o estética neobarroca (Calabrese, 1994: 60). En esta teoría, la reiteración entronca con las ideas de "la variación organizada, el policentrismo y la irregularidad regulada, el ritmo frenético”. En el vídeo musical se encuentra la analogía a esta estética de la repetición en la disposición de los planos y en la construcción de un discurso que aparentemente está basado en el caos y en la velocidad pero que responde a un cuidadoso plan de rodaje y montaje, aludiendo a esa irregularidad regulada observada por este autor.

De otro modo, puede analizarse como una estrategia de simplificación de los mensajes dispuestos en el videoclip atendiendo a una necesidad interna del formato. El vídeo musical está condicionado a una duración restringida y debe condensar las ideas en esa temporalidad, por lo que un eficaz mecanismo de fijación en el espectador es la repetición, tanto de planos como de estructuras estéticas.

Esta característica se encuentra vigente de forma explícita en algunos de los vídeos musicales dirigidos por Michel Gondry. Sirven de ejemplo "Bachelorette” (1997) de Björk y “Come Into My World” (2002) de Kylie Minogue. En ambos se encuentra una configuración cíclica en la que se repiten los mismos patrones una y otra vez como si el espectador estuviese inmerso en un tiovivo. En el primero de ellos se narra una historia que se repliega sobre sí misma, mostrando un único hecho de distintas formas, cada vez más simplificadas. 
En el videoclip de Kylie Minogue, las mismas acciones y los mismos escenarios se presentan al espectador de forma repetitiva a la vez que la intérprete de la canción se va multiplicando a lo largo del vídeo. A través de los recursos visuales con los que cuenta el vídeo musical se crea la sensación de circularidad espacial, ya que se crea un espacio en el que el espectador (a través del objetivo de la cámara) se dispone como centro y la acción se desarrolla alrededor de este mientras la cantante interpreta la letra de la canción al mismo tiempo que interpela al receptor.

El recargamiento en el vídeo musical alude al desfile de metáforas visuales, de elementos que construyen la escena a partir del intercalado de imágenes y sonidos. El exceso de planos se convierte en un lugar común del género. A ello se une la mezcla de una narración intrépida -en el caso de que exista narración-, de la voz, la música, los sonidos ambientales, la luz, la puesta en escena y todas aquellas piezas que conforman el entramado audiovisual del videoclip. Incluso en los vídeos musicales de tipo minimalista existe un recargamiento formal, a veces fruto inevitable de la unión del plano visual y el plano sonoro.

Este barroquismo visual forma ya parte del género del videoclip de tal forma que se ha convertido casi en un requisito estético, aportando una sensación de familiaridad en el espectador que le permite distinguirlo de otros formatos similares como el cortometraje o el spot publicitario. Es decir, el recargamiento expuesto en ellos a través del uso del color, el vestuario, el maquillaje y otros recursos visuales se ha transformado en un indispensable del vídeo musical como se observa en la tónica de los últimos años, tal y como se aprecia en los videoclips de Lady Gaga o Nicki Minaj.

En ocasiones resulta imposible para el espectador descodificar todos los elementos dispuestos en la escena por lo que el videoclip en cuestión necesita una revisión, rompiendo con la idea asociada al género del rápido consumo y de la cultura de usar y tirar. La realidad representada en "Judas" (2011) de Lady Gaga (dirigido por la propia cantante y Laurieann Gibson) se encuentra repleta de iconografía cristiana referente a Jesucristo, los doce apóstoles y María Magdalena (interpretada por Lady Gaga). En el vídeo se crea un horror vacui a partir de la escenografía y los múltiples bailarines que componen la escena. La sensación de recargamiento se acentúa a través del maquillaje, el vestuario, los distintos escenarios y el uso del color, entre otros elementos. No hay espacios vacíos ni se permite al espectador un segundo para analizar lo que está viendo. Todo ello se completa con una narración basada en la traición de Judas a Jesucristo.

La idea de velocidad se encuentra fuertemente asociada al vídeo musical, siendo al mismo tiempo uno de los rasgos de la era postmoderna. Sobre dicho concepto, Calabrese (1994: 70) desarrolla su discurso en torno a la idea de que en el vídeo musical, como también en los videojuegos, se halla una forma de tiempo basado en una "velocidad inusitada". El autor opone este tipo de temporalidad a la que se encuentra en la realidad, por lo que la adjetiva como sintética, se trata, por tanto, de un tiempo artificial, creado. Supone la superación del límite superior del umbral de percepción natural del espectador, quien requiere respuestas igualmente rápidas para poder seguir la trama narrada, en este caso en el videoclip. 
Así, este tipo de velocidad se encuentra en muchos de los géneros de los medios de masas, lo que ha tenido como consecuencia la aparición de una generación de espectadores que poseen habilidades innatas para la decodificación de este lenguaje audiovisual basado en la aceleración y el cambio de una forma realmente veloz. Julian Temple, quien ha dirigido videoclips para Rolling Stone y Sade entre otros, afirma en este sentido que "el vídeo ha tenido un impacto tremendo, ha incrementado la velocidad con la que una nueva generación puede leer y asimilar imágenes. Es una generación mucho más sofisticada, visualmente, que las anteriores. Creo que los vídeos musicales han acentuado la importancia de la información, la ironía visual, y han influido en la publicidad" (Pérez-Ornia, 1991: 133). Deja de ser necesaria tanto la dilación como la linealidad narrativa para la inteligibilidad del mensaje, ya que los receptores han adquirido las capacidades para una exitosa lectura, al encontrarse inmersos en la sociedad de la información y de la comunicación de masas.

Este recurso no resulta arbitrario en la estética clip. Gómez-Alonso (2001: 90) dispone que la velocidad actúa como una técnica visual creadora de impacto. La sensación temporal creada artificialmente en el videoclip se fundamenta en las imágenes y los sonidos. El autor expone que el impacto se crea a través de dos combinaciones: imágenes vertiginosas unidas a sonidos lentos, e imágenes ralentizadas junto a sonidos rápidos. Ambas composiciones inciden en el dinamismo y en el mensaje que se quiere transmitir con el vídeo musical.

La velocidad de los planos también responde a una necesidad del formato. Las imágenes se encuentran supeditadas a la estructura musical que tiene una duración media de cuatro minutos. De este modo, el despliegue estético, técnico y narrativo debe realizarse en ese intervalo de tiempo. Excepcionalmente se hallan videoclips en los que la canción es solo una excusa para crear una narración más amplia, como es el caso del vídeo musical de "Thriller” (1984) de Michael Jackson, dirigido por John Landis. La canción original tiene una duración de cinco minutos y cincuenta y ocho segundos mientras que el vídeo musical dura casi catorce minutos. No es este un caso aislado, son numerosos los videoclips que amplían a través de las imágenes la duración de la banda sonora, rompiendo así con la idea de que la banda icónica se encuentra supeditada a ella. Sirve como ejemplo "Stan" (2000) de Eminem y dirigido por Phil Atwell y Dr. Dre, en el que antes de que comience la canción se incluye una breve introducción que nos presenta a los personajes principales.

\subsection{Fragmentación y narración}

La combinación de repetición y velocidad desembocan en otro de los rasgos postmodernos observados en el vídeo musical: la fragmentación. Sobre esta característica, Salabert (2000: 78) ofrece un análisis de las cualidades del formato que se encuentra sintetizada a continuación: "Se superpone, entonces, el fragmento al todo, la intermitencia a la linealidad, lo múltiple a lo compacto, la aceleración a la lentitud, lo expandido a lo condensado, el story sobre la history”. Para el autor, el videoclip rompe con la modernidad al no encontrarse sujeto a ninguna norma, ya que "se olvida de posiciones preceptivas o dictatoriales y practica la saludable veleidad y la inconstancia”. La fragmentación en el vídeo musical se traduce en 
la deconstrucción de la estructura clásica temporal en forma de flashback, flashforward, mezcla de formatos, acciones representadas de forma simultánea y cualquier efecto que contribuya a la ruptura del tiempo lineal.

Igualmente, González-Requena (1999: 35-36) aprecia en los discursos televisivos la fragmentación pero también la continuidad. En el clip la primera se da en los cortes producidos entre los vídeos musicales, mientras que la continuidad se produce manteniendo ese flujo en los canales temáticos y que se traduce en la programación, definida en términos de continuidad como "el procedimiento que religa los fragmentos en función a las exigencias no ya de los textos parciales de origen, sino a las de la estructura general de la programación”, y a la que suma la carencia de clausura, es decir, la ausencia de un final en las programaciones monográficas, que ofrece al espectador la ilusión de prolongación.

Siguiendo esta línea, y en relación a la fragmentación unida a la temporalidad, Villafañe y Mínguez (2009: 326) suscriben que "la necesaria brevedad de los mensajes obliga a una planificación muy rápida que introduce un elevado número de planos en un tiempo muy reducido". Así, la fragmentación se produce en el interior del videoclip aludiendo a una característica intrínseca del mismo, su temporalidad condicionada por la breve duración de la banda sonora. El discurso publicitario, y por extensión el vídeo musical, muestra lo que González-Requena (1999: 112) denomina sistemática fragmentación que se produce cuando se rompe el marco comunicativo del discurso y "el fragmento solo es consumible en una economía escópica, espectacular, que se desenvuelve al margen de todo proceso de lectura”. De este modo, se observa cómo son varias las características que se ven influidas por la breve temporalidad del clip: repetición, velocidad y fragmentación. Este rasgo se convierte en vector de estas propiedades, que a la vez se encuentran unidas entre ellas.

En el mismo sentido, Pérez-Yarza (1997: 78) afirma que "los clips que tratan de generar un sentido, más allá de la mera ilustración con imágenes decorativas como telón de fondo, recurren a una extrema fragmentación de planos, no solo por estética o como recurso morfológico para marcar el ritmo narrativo, sino también por la necesidad de ampliar el nivel de condensación informativa”. De este modo, la fragmentación no es solo un rasgo estilístico sino también un medio para concentrar toda la información posible, asignando al espectador-receptor la tarea de descodificación de la misma en un tiempo constreñido y limitado por la música que actúa de base. En este aspecto coincide con la naturaleza sintetizada del espot publicitario.

La narración en el vídeo musical se caracteriza en primer lugar por la presencia/ausencia de la misma ya que en este género no es imprescindible la estructura narrativa para la creación de los mecanismos de seducción. Si existe narración, esta suele presentarse de forma aleatoria, sin seguir la linealidad propia de la cinematografía clásica y abundando recursos como el flashforward y el flashback que rompen esa continuidad. Así, la narración se encuentra interrumpida por planos del cantante interpretando el tema de base, siendo estos el objeto central de la promoción y quedando el relato en un segundo plano. 
En relación con la narración y sobre la desconexión entre el montaje y la trama, Picard (1987: 51) apunta como característica de la postmodernidad -que extrapola al vídeo musical- la impureza y lo imprevisible: "El videoclip que, por un montaje videográfico, sintetiza varias imágenes en una o integra una imagen en varias, opera pues según una lógica de impureza, inherente a su especificidad como medio". En él, la imagen prevalece sobre la trama, ausente de forma general y la estética se crea a partir del montaje.

Así, a diferencia del cine, el montaje no se usa para acentuar y puntuar sobre el desarrollo de la historia ni sobre las sensaciones extraídas de la misma, sino que se construye como un mecanismo más, generador de velocidad, sorpresa e impacto y, en definitiva, de seducción. El montaje cinematográfico es un recurso narrativo mientras que el montaje clip supone una técnica sugestiva. De este modo, la disociación montaje-trama resulta lógica en el videoclip ya que, como se ha apuntado anteriormente, en este formato no siempre se encuentra una narración mientras que invariablemente existe un montaje significativo de los planos al margen de un relato.

Sin embargo, a pesar de la naturaleza performativa del vídeo musical son numerosos los clips que desarrollan una historia. Generalmente estas narraciones suelen mantener la estructura clásica de planteamiento, nudo y desenlace, aunque en otras ocasiones estas partes se presentan de forma aleatoria, es decir, pudiéndose encontrar el desenlace al principio del videoclip. "Coffee \& TV" (1999) del grupo Blur y dirigido por Garth Jennings combina el relato con la actuación. En este vídeo musical se narra la historia de una familia preocupada por la desaparición de su hijo, miembro de la banda. Al mismo tiempo se intercalan escenas del grupo tocando en una habitación. En este sentido se presenta el vídeo dirigido por Marc Klasfeld para la canción “Last Friday Night” (2011) de Katy Perry. En él, la cantante es la protagonista de una noche de diversión adolescente que se presenta de forma casi lineal, interrumpida por ensoñaciones de los personajes y flashbacks. La historia es el eje de este videoclip en el que no aparece ningún tipo de actuación aunque se mantiene la vocalización de la canción por parte de la solista que sirve al mismo tiempo como interpelación al espectador.

\subsection{Transdiscursividad}

La transdiscursividad es la relación de un texto con otros textos. Se manifiesta en fenómenos como la intertextualidad, la paratextualidad, la hipertextualidad, la hipotextualidad y la architextualidad. Gómez-Alonso (2001: 74) afirma que "el análisis transdiscursivo empieza a tomar vigencia frente al modelo narrativo tradicional”. En el vídeo musical esta afirmación cobra más importancia al tratarse de un formato visual generalmente performativo -aunque en la actualidad se observa una tendencia hacia la micronarración vinculada con los nuevos soportes en los que se visionan los clips y la gran difusión de los mismos en internet en detrimento de los canales temáticos-y altamente influido por otros medios.

En el vídeo musical se encuentra con frecuencia la intertextualidad, entendida como "la presencia efectiva de un texto en otro" (Gómez-Alonso, 2001: 80), es decir, los distintos géneros encuentran cabida en el videoclip a modo de referencia, 
cita, alusión, convirtiéndose en un hipertexto. En el vídeo musical se alude a elementos de otros medios como la publicidad, la televisión, el cine, el teatro, la danza, el arte, el cómic y, en general, todos los medios que hacen uso de un lenguaje visual y de masas.

La intertextualidad garantiza la construcción del sentido basado en otros textos audiovisuales ya conocidos por el espectador, concediéndole a este un papel fundamental en la significación y resignificación de los contenidos. Calabrese (1994: 73) apunta que los géneros del espectáculo, entre los que se puede incluir al vídeo musical, se acercan cada vez más a otros géneros al traspasar sus propias fronteras. Afirma en este sentido que "un spot publicitario a menudo es ya análogo a un videoclip", haciendo referencia por un lado al carácter publicitario del videoclip y, por otro lado, al uso frecuente del product placement en los vídeos musicales y de la estética clip en el spot, acercando a ambos formatos.

Los estereotipos del mundo publicitario se observan en numerosos vídeos musicales, ya que suponen una fuente creativa y a veces de parodia para este género. En "Intuition" (de 2003 y dirigido por Marc Klasfeld) de Jewel se hacen referencia a spots reales de marcas muy conocidas por el espectador como Sprite, Nike, Levi's y Corona (publicidad encubierta), además de hacer uso de los arquetipos de la moda y la publicidad. De igual modo sucede en "BEP Empire" (2000) del grupo Black Eyed Peas y con Brian Beletic como director. En este videoclip se hace referencia a estructuras propias de la publicidad fácilmente reconocidas por el espectador, ya que adopta la apariencia de un infocomercial.

También existen vídeos musicales que aluden a otros medios como el cine o los videojuegos. Es el caso de “The Kill” (2006) de Thirty Seconds To Mars (dirigido por Bartholomew Cubbins) en el que se recrea la película El resplandor (1980) con la banda como protagonista, apelando a escenas y momentos famosos del film para conseguir la empatía y la atención del espectador. Otra forma de interacción entre videoclip y cine se expresa a través de los vídeos musicales de canciones que forman parte de la banda sonora de una película y que incluyen escenas de la misma. La canción de Jamiroquai “Deeper Underground" fue usada en la película Godzilla de 1998. El vídeo musical, dirigido por Mike Lipscombe, comienza en un cine en el que los espectadores están visionando el film promocionado con gafas 3D. Poco después comienza a desarrollarse una acción casi apocalíptica -el monstruo Gozdilla invade la sala de cine-coincidente con la aparición del cantante y del comienzo de la primera estrofa. El clip continúa en esta línea, intercalando escenas de la película. De este modo, el vídeo musical tiene un doble valor comercial, ya que promociona tanto el film como la canción y al artista.

Por su parte, los videojuegos han tenido también su influencia en el videoclip, sirviendo como un notable ejemplo "Californication” (2000) de Red Hot Chili Peppers (dirigido por Jonathan Dayton y Valerie Faris) en el que los componentes del grupo se transforman en los personajes en 2D de un videojuego. En el clip de 2009 de Chris Garneau "Fireflies" (dirigido por Daniel Stessen) el cantante aparece caracterizado como un personaje tipo The Legend of Zelda y muestra una narración en el mismo sentido. 
Existen otras formas de transdiscursividad que se dan en el vídeo musical. En ocasiones un videoclip sirve también como spot, sufriendo escasas alteraciones en el montaje y en la duración. Así, la cantante Florrie Arnold fue elegida para el spot del perfume L' Elixir de Nina Ricci de 2010. Tanto para el anuncio como para el videoclip, Florrie interpretó una versión de la canción “Sunday Girl” (original del grupo Blondie de 1979). No aparecen diferencias notables entre spot y videoclip. En el primero, la luz que la protagonista toca al final es sustituida por el perfume y se añade digitalmente el slogan acompañado de la voz en off. De similar forma sucede en el vídeo de Marco Dos Santos feat Zita para la canción "Not on the Guest List" que sirvió de inspiración para el spot del perfume de Carolina Herrera 212 VIP.

En el clip original, en blanco y negro, aparecen imágenes de multitud de personas en un club nocturno con ambiente festivo. El anuncio mantiene la misma estética y la única diferencia es la inclusión de personas famosas del mundo de la moda junto a la inserción de subtítulos y slogans. Así, se aprecia cómo existe una relación bidireccional en la influencia de otros géneros en el vídeo musical y de este hacia otros formatos cercanos, como el cine y la publicidad.

Numerosos vídeos musicales realizan citas a otros videoclips. Este fenómeno se denomina autorreferencialidad y se da de forma frecuente en el medio audiovisual. En los vídeos musicales este rasgo puede tener dos tratamientos distintos: parodia y homenaje. En el primer caso, se alude a otro artista o vídeo musical a través de los escenarios o vestuarios con la intención de realizar una crítica ácida y burlesca. A menudo la sátira se hace de una forma muy directa acerca de un videoclip muy particular como son los casos de "All the Small Things" (1999) de Blink-182 (Con Marcos Siega como director) o "Stupid Hoe" (2011) de Nicki Minaj y dirigido por Hype Williams. En otras ocasiones, la parodia se realiza sobre una entidad más amplia, como es el caso de "Windowlicker” (1999) de Aphex Twin (director: Chris Cunningham), que realiza una caricatura de los estereotipos usados en los vídeos musicales del Hip Hop. Acerca de este vídeo musical, Loría (2004: 20) afirma que en él se observa "el regodeo del director en los clichés de la moda rap como cultura de calle".

Como se ha comentado anteriormente, el carácter autorreferencial del videoclip puede darse de un modo laudatorio. Sirven como ejemplo los clips de Keri Hilson “Pretty Rock Girl” (2010) (con Joseph Khan como director) y del grupo Red Hot Chili Peppers "Dani California” (2006) dirigido por Tony Kaye. En ambos casos se presenta a los intérpretes del tema con estéticas que son rápidamente identificadas por el espectador al hacer referencia a cantantes o bandas importantes de la Historia de la música Rock y Pop. Así, el mensaje se construye a partir de la reproducción de vestuarios y escenarios que suponen lugares comunes para el receptor.

\subsection{Espectáculo, seducción e impacto}

El espectáculo supone un fuerte recurso expresivo del vídeo musical. González-Requena (1999: 55) define el espectáculo como "la puesta en relación de dos factores: una determinada actividad que se ofrece y un determinado sujeto que la contempla. Nace así el espectáculo, de la dialéctica de estos dos elementos que se materializa en la forma de una 'relación 
espectacular'“. El autor relaciona este rasgo con el sentido de la vista principalmente y con una relación de seducción entre el espectador y el acto observado. Esta característica se materializa estéticamente en el "culto a lo superficial", como señala Lipovetsky (2004: 240), con el uso de motivos procedentes de la moda y de la cultura de masas.

El mencionado autor afirma en este sentido que "la fuerza de la percusión rítmica pone fin al universo de la profundidad y de la ensoñación diurna; no nos queda más que una estimulación pura, sin memoria, una recepción moda”. La espectacularidad clip se presenta a través de estéticas imposibles y el uso de nuevas tecnologías como la infografía y el diseño gráfico. Son frecuentes los vídeos musicales que recurren a la animación y a los efectos especiales como sucede en el vídeo de The Prodigy “Warrior's Dance” (2009), dirigido por Corin Hardy, creado a partir de la técnica del stop-frame con los que se da vida a unas figuras humanoides construidas con cajetillas de cigarrillos que comienzan a bailar como en una fiesta.

El vídeo musical forma parte de una estrategia publicitaria llevada a cabo por la industria discográfica. Teniendo presente esta idea no puede obviarse la seducción como uno de los rasgos principales del formato. La fascinación clip se construye a través de los colores, las texturas, la composición y el cambio frenético de planos que crean un ambiente casi de hipnosis en el espectador.

La narración puede servir como mecanismo de seducción pero generalmente es sustituida por la atrayente presencia del cantante o del grupo protagonista, que dirigen su actuación hacia la cámara-identificada directamente con el espectadorcomo mecanismo para retener el interés del consumidor. A este respecto, Gómez-Alonso (2001:54) afirma que "las imágenes que pueblan los discursos audiovisuales contemporáneos, esencialmente los publicitarios, interpelan constantemente al espectador de forma directa o indirecta presentando cierto grado de seducción ante lo que se consume". Toda la estética proyectada en el vídeo musical pretende la captación permanente de la atención de la audiencia.

La seducción en el vídeo musical se articula a través tanto de imágenes bellas como de otros mecanismos basados en la provocación. Se apela a la política, el sexo, la religión, la violencia o lo grotesco. Sirven de muestra los vídeos de Madonna "Like a Prayer" y "American Life". El primero de ellos de 1989 y dirigido por Mary Lambert, envuelto en polémica por incluir simbología cristiana y donde la cantante muestra una actitud erótica con un santo negro en el interior de una iglesia. En 2003, Madonna basó su vídeo musical “American Life” (dirigido por Jonas Åkerlund) en la provocación de tipo político. En él aparece vestida con ropa militar, con numerosas banderas de fondo y aludiendo al ex-presidente estadounidense George W. Bush y al conflicto contra Irak. Existen varias versiones del vídeo para tratar de escapar de la censura norteamericana. La incitación sexual supone un potente recurso visual para el vídeo musical, son numerosos los clips que acuden a la exhibición explícita de desnudos y actitudes sexuales, siendo claros ejemplos “Dirrty” (2002) de Christina Aguilera (con David Lachapelle como director) y "All the Things She Said" (2002) de t.A.T.u. y dirigido por Ivan Shapovalov. En el lado de la estética de lo grotesco destacan los vídeos musicales de Marilyn Manson, tomando como evidencia el clip para 
la canción “The Beautiful People” (1996) dirigido por Floria Sigismondi, en el que aparecen maniquíes, insectos y un ambiente oscuro y enfermizo.

Otros mecanismos de los que se sirve la seducción visual son la sorpresa y el impacto, rasgos que entroncan con la estética postmoderna. Gómez-Alonso (2001: 87) afirma que "los relatos postmodernos (...) adoptan diversas estrategias audiovisuales con el fin de seducir y atrapar la mirada del espectador. Los procedimientos que se reflejan con mayor asiduidad en las coordenadas espacio-temporales de la narración son el impacto y la velocidad". Estos mecanismos provocan en el espectador gran atracción, ávidos de sensaciones y experiencias nuevas y excitantes. Por otra parte, el espectador del vídeo musical debe descifrar un mensaje que se muestra siempre entrecortado por bruscos cortes de planos y cuya combinación de sonido e imagen genera una impactante huella. Lipovetsky (2004: 204) sostiene que en el videoclip las imágenes representan un estímulo, solo válido en ese instante.

A menudo el videoclip recurre a la narración para crear un impacto o sorpresa final que el espectador que está siguiendo la historia no espera. En "I Could Be the One (Nicktim)" (2013) de Avicii vs Nicky Romero (dirigido por Peter Huang) se presenta a una chica que, aburrida de la vida que lleva en la oficina, comienza una ensoñación de tipo hedonista y cómica donde abundan la belleza y la riqueza. Al final del vídeo decide romper con esa rutina pero al salir de la oficina es atropellada por un camión. Este ejemplo sirve para reflejar cómo la sorpresa no es solo provocada por los efectos y técnicas digitales novedosas sino que a través de la narración se consigue el impacto deseado y también la captación del espectador intrigado por el desarrollo de la historia.

En otros casos recurre a la oposición entre el significado de la letra de la canción y las imágenes asociadas a ella. Este contraste crea un choque en el horizonte de expectativas del espectador, lo que genera el impacto y su perduración en la memoria. Sirve de ejemplo el vídeo musical de Bastille "Of the Night” (2013), dirigido por Dave Ma, en el que la música y la letra de tono festivo contrastan con las imágenes de escenarios de crímenes observados por un investigador privado. Los cuerpos sin vida interpretan la letra en este clip mientras miran directamente a la cámara en el que no aparece la banda. El ejemplo contrario lo constituye el vídeo musical de Pharrell Williams "Happy" (2013). El clip, dirigido por el colectivo WAFLA (We Are From Los Ángeles), muestra al cantante en distintos lugares y situaciones intercalado con imágenes de otras personas anónimas y famosas como Jamie Foxx o Kelly Osbourne, entre otros, interpretando la letra de la canción mientras realizan bailes y movimientos que evidencian la actitud festiva y alegre que refleja la letra de la canción. Aparecen también personajes de la película Mi villano favorito 2, ya que la canción forma parte de la banda sonora del film.

Por otra parte, los mecanismos de sorpresa e impacto constituyen un valor para la difusión del producto a través de la recomendación entre usuarios, quienes, sorprendidos por el clip, lo compartirán con otros posibles espectadores contribuyendo a la difusión de tipo tradicional (boca-oreja) del mismo. En ocasiones, el vídeo musical impacta de tal 
forma en el público que es imitado y/o parodiado de forma viral a modo de vídeos caseros que serán difundidos a través de webs como YouTube que permiten que los usuarios aporten sus propios contenidos.

\section{Conclusiones}

Tras el desarrollo de las características de la postmodernidad halladas en el vídeo musical se deduce que este formato, esencialmente publicitario pero también basado en la experimentación con las técnicas, asume estos rasgos como heredero del tiempo que lo creó. El arte posee gran influencia en este producto cuyo objetivo es dual: por una parte, una finalidad económica como mercancía fabricada por la industria cultural; y por otra parte, el clip persigue un fin artístico, de vanguardia y experimentación visual. Por ello, hace uso de numerosos recursos que facilitan la consecución de ambos objetivos.

El videoclip es un paradigma del pastiche postmoderno ya que supone el mejor ejemplo de un formato creado a partir de otros cuyo resultado se muestra como novedoso. Se trata de un puzle, de un mosaico de imágenes que se superponen para producir un producto nuevo que se presenta como original pero que no es más que la suma de otros medios audiovisuales como la televisión, el cine o la publicidad. El vídeo musical no podría ser creado de otro modo, su naturaleza experimental así como su capacidad para tomar influencias de distintos géneros para incorporarlos a una nueva creación original lo posicionan en el centro de la postmodernidad.

Por otra parte, la brevedad que caracteriza al clip incide en la necesidad de la repetición y la velocidad, la primera con el fin de asegurar la recepción del mensaje que se quiere transmitir en él -y generalmente relacionado con la imagen del artista- mientras que la segunda es la respuesta a la necesidad impuesta por la corta duración del clip por lo que la información debe aparecer condensada y a la mayor velocidad posible para que llegue al espectador. Igualmente, este rasgo es también un elemento de seducción dentro del aparato retórico, creando impacto y atrapando la atención de los receptores.

La fragmentación es un recurso que favorece el mosaico clip. La ruptura es una de sus principales características ya que el vídeo musical trata de transgredir los códigos visuales tales como la temporalidad, la narración, el espacio videográfico, la relación de las bandas sonora e icónica y el resto de elementos relativos a las propiedades de la imagen. Su finalidad es la creación de piezas originales que atraigan la atención del espectador. Para ello recurre a numerosos mecanismos como el recargamiento y el barroquismo visual. La profusión de elementos dotan de una apariencia característica al vídeo musical, alejándolo de medios similares como el spot publicitario o el cortometraje.

En esta línea, Lipovetsky y Serroy (2015: 246) afirman que "las imágenes se suceden sin organización lineal ni relación evidente con la letra de las canciones, los montajes son sincopados, las puestas en escena rivalizan en extravagancia, 
desquiciamiento e ironía, explotando las fragmentaciones, las multiplicaciones y yuxtaposiciones de figuras, así como la rapidez extrema en el paso de las imágenes".

Por su parte, los videoclips narrativos se presentan como breves piezas en las que el relato aparece distorsionado por las leyes de este formato. La adaptación de las imágenes a la banda sonora, la brevedad y la velocidad inciden en la creación de una estructura narrativa que aparece subordinada a la música pero que a la vez se independiza de esta creando un producto transgresor y basado en la ruptura de los códigos de la cinematografía clásica.

La visible influencia de los medios en el vídeo musical se hace aun más patente a través de la transdiscursividad. Las citas, las parodias y los remakes son numerosos en el género clip ya que suponen una referencia que el espectador descodifica más fácilmente e incide en el arraigo del mensaje. La intertextualidad se torna fuente de inspiración y de recursos para el videoclip, adaptando los tópicos a su propio estilo.

El videoclip, como el resto de géneros audiovisuales, son pura espectacularidad. El espectáculo y la seducción son la razón de su existencia. Este formato surgió con la llegada de la televisión y gracias al auge de la tecnología vídeo como un modo con el que hacer llegar al cantante a un público masivo a través de la creación de un producto seductor con la misma duración que la canción de base. El clip evolucionó del registro simple de las actuaciones de los artistas realizando el playback del tema musical hacia piezas narrativas, experimentales y artísticas que requerían de un mayor aparato seductor y que se basaban en la sorpresa, el impacto y la incorporación de novedosas técnicas para retener la atención de un espectador cada vez más versado en la rápida descodificación de los mensajes audiovisuales. Como sostienen Lipovetsky y Serroy (2015: 247) el videoclip supone un "bombardeo sonoro y visual, mosaico de imágenes-flash, deconstrucción del orden clásico: el producto comercial musical ha absorbido los principios vanguardistas del arte moderno”.

Se concluye de este modo que el vídeo musical es un formato intrínsecamente postmoderno, reflejo de las características de esta era a través de su estética, de su naturaleza y de sus rasgos formales. Es una muestra de la época en la que fue concebido y desarrollado como vehículo transmisor de la ideología del consumo impuesta por las modas y las industrias culturales. Así, la postmodernidad supone el contexto ideológico en el que se produce el videoclip, impregnado de ella, por lo que se facilita la identificación de sus rasgos generales y su posterior análisis.

\section{Referencias bibliográficas}

Ariza, M. y Gandini, L. (2012): "El análisis comparativo cualitativo como estrategia metodológica", en Ariza, M. y Velasco, L. (coords.): Métodos cualitativos y su aplicación empírica. Por los caminos de la investigación sobre la migración internacional. México: Instituto de Investigaciones Sociales y Colegio de la Frontera Norte.

Calabrese, O. (1994): La era neobarroca. Madrid: Cátedra. 
Gómez-Alonso, R. (2001): Análisis de la imagen: Estética audiovisual. Madrid: Laberinto.

González-Requena, J. (1999): El discurso televisivo: Espectáculo de la posmodernidad. Madrid: Cátedra.

Harris, M. (2000): Teorías sobre la cultura en la era posmoderna. Barcelona: Crítica.

Jameson, F. (1999): El giro cultural. Escritos seleccionados sobre el posmodernismo 1983-1998. Buenos Aires: Manantial.

Lipovetsky, G. (2004): El imperio de lo efímero. La moda y su destino en las sociedades modernas. Barcelona: Anagrama.

Lipovetsky, G. y Serroy, J. (2015): La estetización del mundo. Vivir en la época del capitalismo tardío. Barcelona: Anagrama.

Loría, V. (2004): "Destellos del lado oscuro", Lápiz, n. 203, pp. 18-23.

Lyotard, J. F. (1996): La posmodernidad (explicada a los niños). Barcelona: Gedisa.

Pérez-Ornia, J. R. (1991): El arte del vídeo. Introducción a la historia del vídeo experimental. Barcelona: Serbal y RTVE.

Pérez-Yarza, M. (1997): "La astuta serpiente. Análisis de un vídeo musical", Semiosfera, n. 6-7, pp. 73-92.

Picard, Y. (1987): "El videoclip: Entre el postmodernismo y el 'star-system'", Comunicación: Estudios Venezolanos de Comunicación, n. 61, pp. 48-55.

Salabert, P. (2000): Estética del todo o teoría de lo 'light'. Valencia: Episteme.

Sánchez-Noriega, J. L. (1997): Crítica de la seducción mediática. Madrid: Tecnos.

Sedeño, A. M. (2006): "Aportaciones del videoclip musical a la carrera artística de una megastar del rock: El caso de David Bowie", Boletín de Arte, n. 26-27, pp. 745-757.

Vattimo, G. (1994): En torno a la posmodernidad. Barcelona: Anthropos.

Villafañe, J. y Mínguez, N. (2009): Principios de Teoría General de la Imagen. Madrid: Pirámide. 